\title{
THE RELIGION OF THE FJORT OR FIOTE
}

\section{"MAVUNGU"}

THE religion of the Fiote or Bavili family of the Kingdom of Loango may be divided into four great parts, two of which may be classed as the spiritual parts and two as belonging to the natural division.

I. Bakici Baci, or the attributes of God on earth, including the King, made in His image, as the speaking I or the preacher.

2. Bilongo, or medicines.

3. Zinkauci $\mathrm{Zi}$ Bakici, fetishes into which nails are driven, used as deterrents, and made by Nganga, who places in them the "passion" required.

4. Bakici Bankondi, household gods or fetishes protecting villages houses or persons, such as charms, etc.

In the creation of the Zinkauci (the aboriginal hearer) $\mathrm{Zi}$ Bakici naturally predestined and necessitated the making of the Bakici Bankondi, and will as naturally disappear with them. It is to these two parts that witchcraft and all its fearful evils are attached.-Ndoxi-ism or witchcraft really means the poisoning of either the mind or the body of the sufferer, and with it may be connected forms of hypnotism, suggestion, and all domination by fear.

Mavungu of the town of Nganzi in Kakongo (Figs. I, 2, 3), was one of the three most powerful $\mathrm{Zi}$ Nkauci in Kakongo, sharing the honour of keeping the country under the domination of fear with his compeers Mbiali-Mundembi and Mangaka ( $\mathrm{I}$ am told that Mangaka was also transported to Europe, and may be found in the Manchester Museum).

These three with other 23 figures of men and animals 
form that class of fetish called Zinkauci $\mathrm{Zi}$ Bakici (which I should translate as the aboriginal negative or opposites of Nkici the

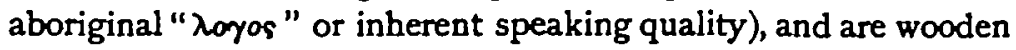
figures into which one or other of the passions of men have been put by certain Nganga (priests, medicine men, or feticheurs). They are the fear inspirers. A wishes to harm B, and so goes to the Nganga or priest, and pays him to hammer a nail or knife or other sharp-pointed instrument into the figure. Or C wishing to be cured of some bad habit allows $D$ to have a nail driven into it. Should D break his promise the fetish causes him and his family endless sickness and trouble and death-so that $\mathrm{D}$ has to search out the fetish and pay the surgeon to extract the nail driven in by order of $\mathrm{C}$. Or $\mathrm{B}$ and his family begin for some unaccountable reason to suffer sickness, etc., and so seek out a "diviner" to tell him what "fetish" it is that is bothering him and his family. The diviner tells him and B has to search out the Nganga and pay him to draw out the nail driven into the fetish by $\mathrm{A}$.

To give you the history of Mavungu is of course impossible, but a long tale of misery hangs on every instrument hammered into him, and the hundreds of those that have been withdrawn.

Nganga Nganzi is now dead, and Mavungu was seized by the Portuguese Government, who in the early ' 90 's fairly raided the country for these figures. Mavungu became the spoil of the Secretary Illusmo Senr. Jose Chichorro, of Cabinda, and was given to Miss Kingsley by his family.

The three great fetishes appear to me to have represented the three great passions connected with Paternity (mkiali mundenchi), Maternity (mavungu) and Reason (Mangaka), but all systematic connection between the fetishes and the passions has long been lost sight of, and all the natives care about is its "fama" or reputed power of working evil.

One of the great "charms" of Mavungu was that when the Nganga rubbed his hands the figure became invisible to those that sought for it. One had to pay ever so much, therefore, to get at it once a nail had been driven into it.

The word Mavungu is not only connected with the idea of reason and maternity, but also with the idea of a covering, hence perhaps invisibility. 
In Kakongo the lower extremities of the figure were covered with a piece of native grass cloth or blue baft. This apparently has been lost, the rounded piece of wood near to the feet is probably the haft of a mative knife, which found a place in the circular cavity formed by the fingers and thumb of the right hand. ${ }^{1}$

\section{R. E. DENNETT.}

\footnotetext{
1 Miss Kingsley believed this to be the only fetish figure in Englend, perhaps in Europe, which still had its "power" on it. The "power" is beld in a bend round the neck chiefly or wholly formed of coagulated humen blood. If this were taken awny the figure would be like any other bit of wood. - [ED.]
} 


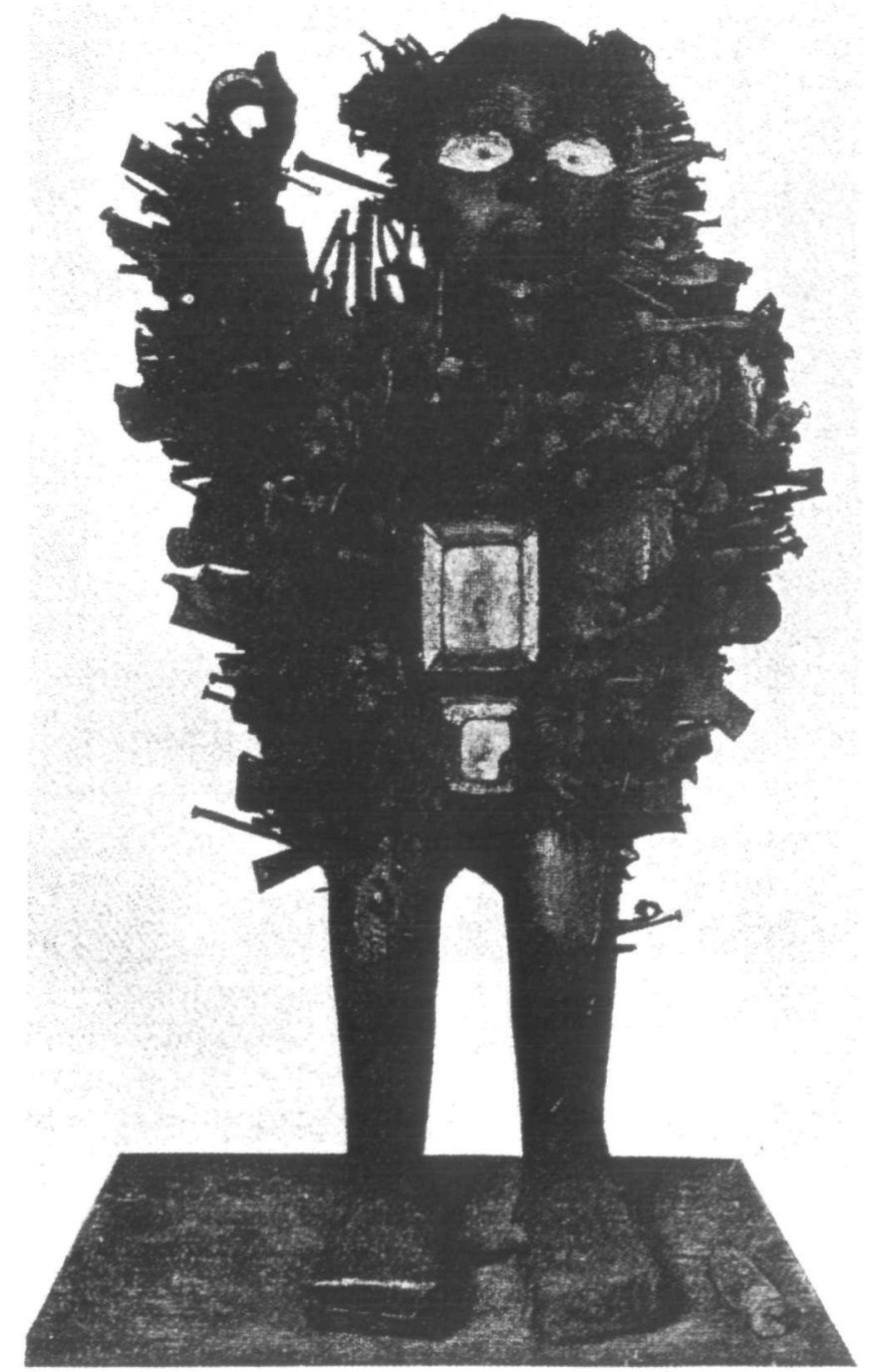

MAVUNGU. Fig. I, 


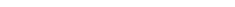




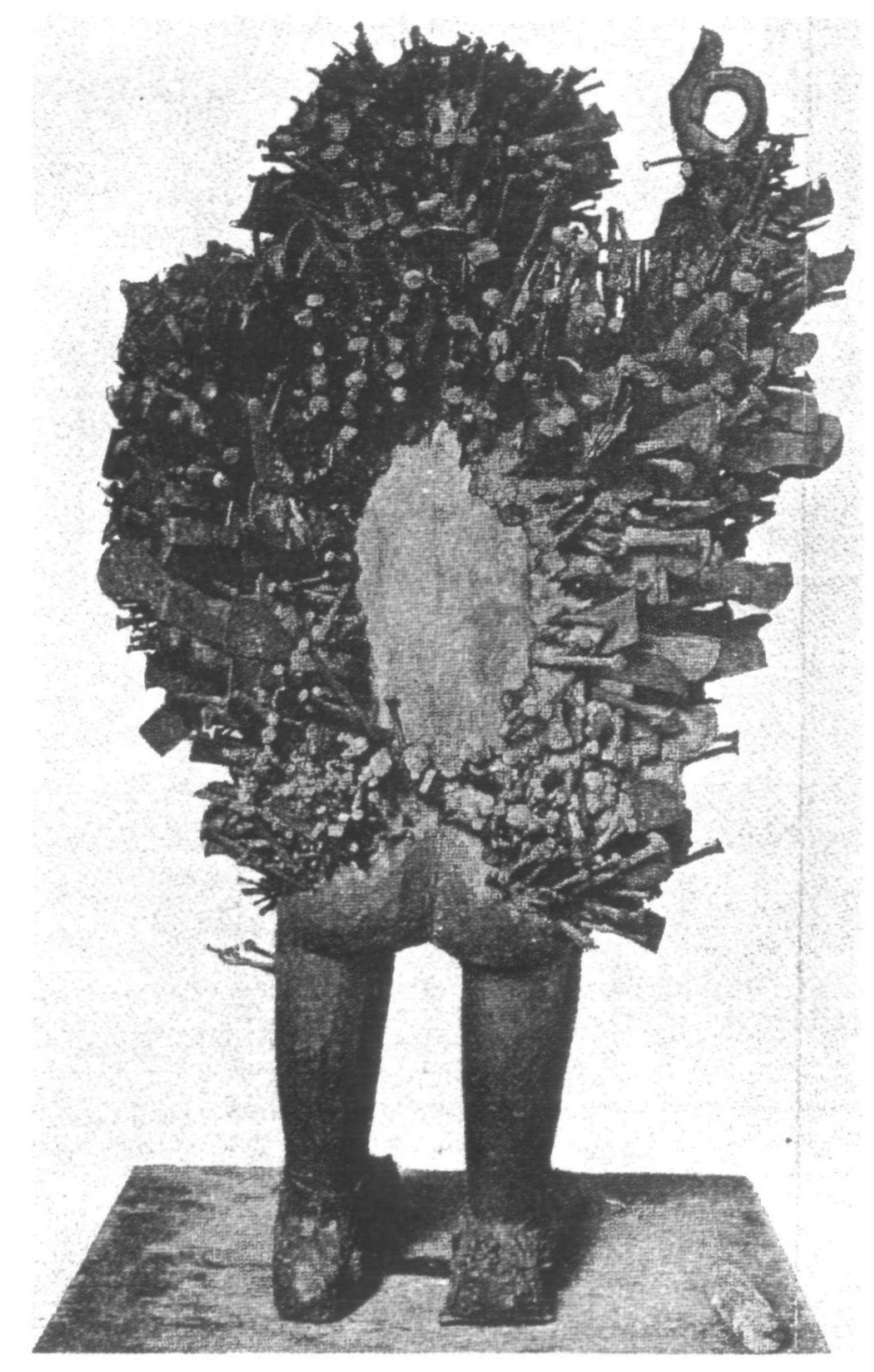

MAVUNGU. Fig. 2.

This Figure was left by MARY Kingsi.Ey to the Pitt Rivers Museum, Oxford. These Plates are reproductions of photographs lent by the Curator of that Museum. 
Downloaded from https://academic.oup.com/afraf/article-abstract/1/IV/452/87020 by University of Durham user

on 21 January 2018 


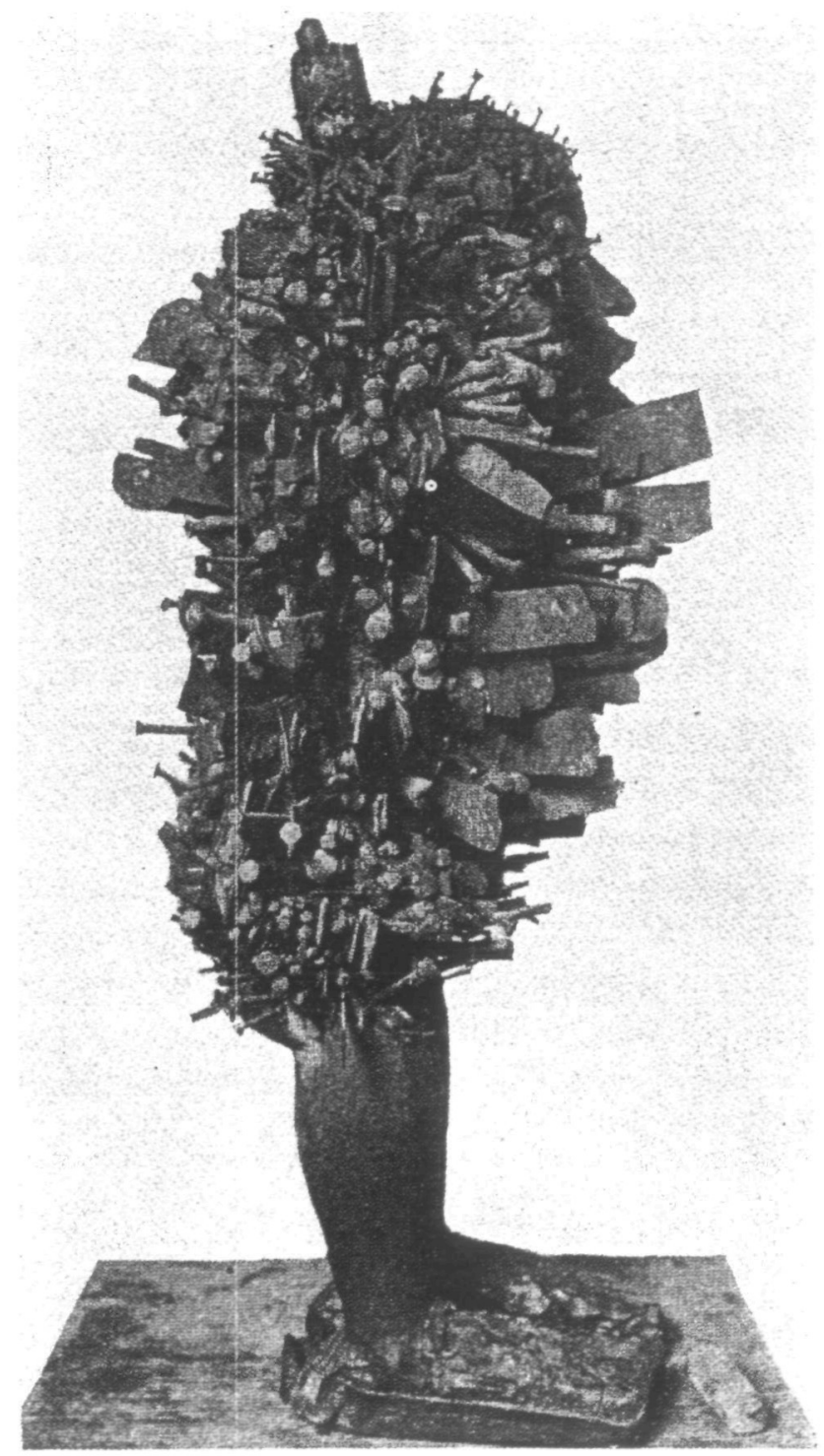

MAVUNGU. Fï. 3 . 
Downloaded from https://academic.oup.com/afraf/article-abstract/1/IV/452/87020 by University of Durham user

on 21 January 2018 